\title{
Lung Function and Inflammation in Adult Sickle Cell Disease in a West Indian Sickle Cell Cohort
}

\author{
Kibileri Williams', Maria Rios', Nicole Dottin', Shani Hughes', Danielle Strachan', Gershwin Davis², Kenneth S Charles² and Terence AR \\ Seemungal $\left.\right|^{*}$
}

${ }^{1}$ Department of Clinical Medical Sciences, Faculty of Medical Sciences, University of the West Indies, St Augustine Campus, Trinidad and Tobago

${ }^{2}$ Department of Paraclinical Sciences, Faculty of Medical Sciences, University of the West Indies, St Augustine Campus, Trinidad and Tobago

\begin{abstract}
Background: The commonest cause of mortality in sickle cell disease (SCD) is an acute condition called the acute chest syndrome. Little is known of the long term effects of this condition or of its effect on lung function.

Objective: To determine lung function in sickle cell disease (SCD) adults and its relation to acute chest syndrome, baseline haemoglobin and systemic inflammation as estimated by serum C-reactive protein.

Methods: The lung function in sickle cell disease (SCD) outpatients was compared to that in asymptomatic age and sex matched controls. Stable haemoglobin and serum C-reactive protein (CRP) were measured.

Results: 74 controls of mean age 31 years and 154 sickle cell disease (SCD) outpatients with mean age 31 with $44 \%$ males were recruited. Controls and sickle cell disease (SCD) patients did not differ in age or sex. $18 \%$ sickle cell disease (SCD) patients had at least one episode of acute chest syndrome and $7 \%$ had two or more episodes. Forced vital capacity was lower in sickle cell disease (SCD) patients than controls and $47 \%$ of sickle cell disease (SCD) patients had a restrictive ventilatory defect. A further $19 \%$ had obstruction but the presence of this abnormality was not related to smoking habit. Patients with a history of two or more acute chest syndrome episodes were more likely to have poor lung function. Haemoglobin was positively correlated with forced vital capacity and inversely correlated C-reactive protein. Multivariate analysis showed that haemoglobin in sickle cell disease (SCD) patients was lower if patients also had a low forced vital capacity, high serum C-reactive protein, low body mass index, older age or male gender.
\end{abstract}

Conclusions: Abnormal lung function is common in sickle cell disease (SCD) adults. In sickle cell disease (SCD), adult's low haemoglobin is related to a restrictive ventilatory defect and systemic inflammation. Severity of stable disease in sickle cell patients is related to poor lung function and systemic inflammation.

Keywords: Sickle cell disease; FEV1; FVC; Restrictive ventilatory defect; Acute chest syndrome

\section{Introduction}

Sickle Cell Disease (SCD) is the most common inherited disorder affecting African and Caribbean populations [1]. Sickle Cell Disease (SCD) represents a spectrum of inherited haemoglobin disorders which include a number of genotypes namely homozygous sickle cell disease (haemoglobin SS disease), doubly heterozygous sickle haemoglobin C disease (haemoglobin SC disease) and the sickle B-thalassemias [2]. These genotypes are associated with a wide range of phenotypes characterized by chronic haemolysis, tissue infarction, and painful episodes [3].

Acute Chest Syndrome (ACS) is a multifactorial process with the likely final common pathway being in situ microvascular thrombosis [4]. It is a life threatening condition and a frequent cause of death among sickle-cell patients being one of the more common causes of their morbidity and hospitalizations $[5,6]$. The prevalence of acute chest syndrome among sickle cell disease (SCD) patients in the Trinidadian population is currently unknown. A 6-month study conducted at the Port-of-Spain General Hospital, Trinidad and Tobago, showed that of 82 admissions for painful crises in sicklers, $13 \%$ were due to the acute chest syndrome [6]. It has also been shown that although acute chest syndrome is often a self-limiting illness, its effects on lung function may be quite significant, leading to life-threatening respiratory insufficiency and some have speculated that it may lead to development of chronic lung disease [7]. Anecdotal reports from our chest clinic suggested that our sickle cell patients may have a restrictive ventilatory defect.

Apart from lung function, blood markers have also been shown to be related to clinical episodes in patients with sickle cell disease.
Lower baseline haemoglobin levels are associated with an increased rate of painful episodes and morbidity in sickle cell disease [8]. Acute phase reactants such as C-reactive protein (CRP) have been found to be significantly elevated in sickle cell patients, particularly in those with homozygous disease [9].

We compared lung function in a group of sickle cell disease (SCD) patients and controls and hypothesized that our sickle cell outpatients have a restrictive ventilatory defect. We also explored relationships between the severity of the anaemia in sickle cell disease patients and lung function variables and serum CRP in this study.

\section{Methodology}

A patient was taken as having the acute chest syndrome (ACS), if this was stated as the medical diagnosis in the hospital discharge notes.

\section{Sample population and inclusion and exclusion criteria}

Sickle cell disease patients: A total of 361 sickle cell disease patients

*Corresponding author: Terence Seemungal, Professor of Medicine, Department of Clinical Medical Sciences, The University of the West Indies, St Augustine Campus, Trinidad and Tobago, Tel: 868663 4332; Fax: +868 663 4332; E-mail: tseemungal@sta.uwi.edu

Received May 02, 2012; Accepted September 11, 2012; Published September 14,2012

Citation: Williams K, Rios M, Dottin N, Hughes S, Strachan D, et al. (2012) Lung Function and Inflammation in Adult Sickle Cell Disease in a West Indian Sickle Cell Cohort. J Pulmon Resp Med 2:129. doi:10.4172/2161-105X.1000129

Copyright: ( $) 2012$ Williams K, et al. This is an open-access article distributed under the terms of the Creative Commons Attribution License, which permits unrestricted use, distribution, and reproduction in any medium, provided the original author and source are credited. 
were registered at the Haematology Clinic, Port of Spain General Hospital. 154 patients (HbSS=143; HbSC $=7$; HbS beta-thal=4) were actually recruited. There was no difference in mean age or gender of sickle cell patients sampled and those not sampled. Twenty-seven of the 154 recruited patients had a history of at least one episode of acute chest syndrome. A history of acute chest syndrome was obtained by direct communication via a questionnaire and confirmed by examination of the patient file for a specific and documented diagnosis of the syndrome. Patients were recruited only if they did not have any existing pulmonary disorders [10], or any medical conditions that may have led to suboptimal results [11] or which may have been exacerbated by the testing procedure [12]. Of the total eligible population, eight patients refused to participate, six were recently deceased, four were excluded for medical reasons namely HIV, viral hepatitis (2 patients) and pregnancy, and 189 patients were unavailable or could not be contacted.

Healthy subjects: We recruited 74 ethnically matched healthy subjects (controls) with a smoking history of less than 5 pack years [13]. All controls had no medical symptoms or history of medical illness and also had normal lung function that is, FEV1 greater than $80 \%$ predicted for age and height and FEV1/FVC greater than $70 \%$.

\section{Ethical review}

The study was approved by the institutional review boards of the University of the West Indies and Port of Spain General Hospital, Trinidad and Tobago. All subjects gave written informed consent.

\section{Lung function}

Spirometry measurements were performed with a hand-held turbine spirometer (MicroSpirometerCat No: MS01 Micromedical Limited P. O Box 6 Rochester, Kent, ME1 2AZ, UK), according to Global Initiative for Obstructive Lung Disease Criteria [14]. Post bronchodilator spirometry was taken for all sickle cell disease patients. Since by definition normal subjects had no history of disease or symptoms of illness, this was not a prerequisite for their spirometry measurements. To calculate the predicted value for lung function, we used the Third National Health and Nutrition Examination Survey (NHANES-III) Hankinson's reference equations for afro-Americans [15], according to age, sex, and height. An obstructive ventilatory defect was defined as an FEV1/FVC ratio less than $70 \%$ while a restrictive ventilatory defect was taken as an FVC\% predicted for age and height of less than $80 \%$.

\section{Other measurements}

Non-fasting venous blood samples were obtained from sickle cell disease patients for serum CRP analysis and plasma samples with ethylene diamine tetra acetic acid (EDTA) as anticoagulant used for haemoglobin determination. Serum CRP concentrations were measured using the Tina-Quant sCRP (Latex) high sensitive immunoturbidimetric assay on the Roche/Hitachi 912 Automatic Analyzer (Roche Diagnostics, GmbH, D-68298 Mannheim). The measuring range was $0.1-20 \mathrm{mg} / \mathrm{L}$ with a detection limit of $0.03 \mathrm{mg} / \mathrm{L}$.

\section{Statistical analysis}

We assumed that controls would have a mean (SD) FEV1 of 100 (12\%) predicted for age and height. At the $5 \%$ level of significance with a power of $95 \%$, we estimated that the sample size required to detect an $8 \%$ difference in mean FEV1 in sickle cell disease subjects was 60 [16]. Data was analysed using SPSS (version 12 for Windows). Normally distributed data were summarised by mean (standard deviation, SD), skewed data by median (interquartile range, IQR) and categorical data by absolute number (percentage). CRP was normalized by log transformation.

\begin{tabular}{|l|l|l|l|}
\hline Variable & Controls & SCD & p-value \\
\hline $\mathrm{N}$ & 74 & 154 & \\
\hline Age & $30.7(10.3)$ & $33.8(12.0)$ & 0.053 \\
\hline Height, $\mathrm{m}$ & $1.71(0.093)$ & $1.69(0.09)$ & 0.064 \\
\hline FEV1 (L) & $3.13(0.62)$ & $2.34(0.66)$ & $<0.001$ \\
\hline FEV1\% & $94.9(11.6)$ & $74.5(13.3)$ & $<0.001$ \\
\hline FVC (L) & $3.83(0.79)$ & $3.13(0.93)$ & $<0.001$ \\
\hline FVC\% & $97.6(12.1)$ & $83.6(16.3)$ & $<0.001$ \\
\hline FEV1/FVC\% & $82.0(5.6)$ & $75.5(11.0)$ & $<0.001$ \\
\hline
\end{tabular}

Abbreviations: SCD: Sickle Cell Disease; ACS: Acute Chest Syndrome; N Number; M: Male; BMI: Body Mass Index

Table 1: Baseline data/confounding variables for 74 controls and 154 sickle cell disease patients. Data are shown as mean (SD) or IQR $\left(25^{\text {th }}\right.$ centile, $75^{\text {th }}$ centile $)$ or number (\%). There were $\mathrm{N}=36(48.6 \%)$ males amongst the controls and 67 $(43.5 \%)$ sickle cell disease patients. BMI for sickle cell disease patients was 21.0 (4.2) kg per square metre.

\begin{tabular}{|l|l|l|}
\hline Variable & Correlation w/ SCD & p-value \\
\hline Age & 0.123 & 0.099 \\
\hline Gender & -0.106 & 0.157 \\
\hline Height & -0.167 & 0.025 \\
\hline FEV1 & -0.566 & $<0.001$ \\
\hline FEV1\% & -0.652 & $<0.001$ \\
\hline FVC & -0.432 & $<0.001$ \\
\hline FVC\% & -0.466 & $<0.001$ \\
\hline FEV1/FVC & -0.317 & $<0.001$ \\
\hline
\end{tabular}

Table 2: Spearman's Correlations amongst never-smokers between baseline variables and presence of sickle cell disease (65 controls and 115 sickle cell disease patients)

Normally distributed continuous variables were compared by $\mathrm{t}$-test; otherwise Mann-Whitney U or Wilcoxon signed ranks test were used.

One-way ANOVA was used to examine the relationship of haemoglobin in sickle cell disease patients with lung function categorized as (A) normal lung function, (B) either restriction or obstruction but not both and $(\mathrm{C})$ both obstruction and restriction. Backward linear regression with plasma haemoglobin as outcome variable was used to examine the relationship between baseline variables and haemoglobin as an estimator of severity of sickle cell anaemia. Gender and all variables with significant univariate relation to $\mathrm{Hb}$ were entered into the multivariate analysis. All data was analysed using SPSS version 12 (for Windows).

\section{Results}

\section{Demographic and physiologic variables: all study participants}

We recruited 154 sickle cell disease patients and 74 controls. CRP data was available for 138 and $\mathrm{Hb}$ data for 149 sickle cell disease patients. The baseline and demographic variables for controls and for sickle cell patients are shown in Table 1. 1.27 (18\%) of the sickle cell disease patients had a history of acute chest syndrome (ACS). 17 (11\%) sickle cell disease patients had one acute chest syndrome episode only, $5(3.2 \%)$ patients had two episodes and 3 patients had three or more episodes. $9(12 \%)$ of controls and $39(25 \%)$ of the sickle cell disease patients sampled were smokers. The normal subjects did not differ from the sickle cell population in age and gender. Sickle cell patients had a mean (SD) height of $1.69(0.88) \mathrm{m}$ and weight of 60.0 (12.4) kg. In the sickle cell disease patients, blood results showed mean (SD) $\mathrm{Hb}$ was $8.97(2.23) \mathrm{g} / \mathrm{dl}$ and median (IQR) CRP was $3.15(1.43,8.58) \mathrm{mg} / \mathrm{L}$.

\section{Lung function in controls vs. sickle cell disease}

Lung function among controls and sickle cell disease patients is 
Citation: Williams K, Rios M, Dottin N, Hughes S, Strachan D, et al. (2012) Lung Function and Inflammation in Adult Sickle Cell Disease in a West Indian Sickle Cell Cohort. J Pulmon Resp Med 2:129. doi:10.4172/2161-105X.1000129

\begin{tabular}{|c|c|c|c|c|}
\hline \multirow[t]{2}{*}{ Number (\%) } & & \multicolumn{2}{|c|}{ Restriction** } & \multirow[t]{2}{*}{ Total } \\
\hline & & No & Yes & \\
\hline \multirow[t]{2}{*}{ Obstruction* } & No & $52(34)$ & $60(39)$ & $112(73)$ \\
\hline & Yes & $30(19)$ & $12(8)$ & $42(27)$ \\
\hline \multicolumn{2}{|l|}{ Total } & $82(53)$ & $72(47)$ & $154(100)$ \\
\hline
\end{tabular}

* Obstruction was defined as FEV1/FVC less than $70 \%$

** Restriction was defined as FVC less than $80 \%$ predicted for age and height

Table 3: The distribution of obstructive and restrictive ventilatory defects in 154 patients with sickle cell disease. The number of sickle cell disease patients (percentage of total) is shown.

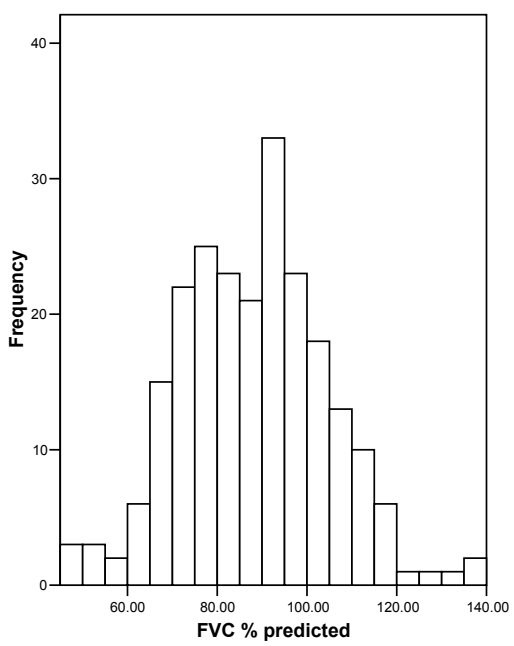

Figure 1: Distribution of FVC\% predicted among 154 sickle cell disease patients.

shown in Table 1. Lung function was higher in controls than in sickle cell disease patients in every parameter measured (Table 1) with controls having a median FEV $1 \%$ of $94 \%$. Median (range) FVC\% in sickle cell disease patients was $82 \%$.

Whether or not smokers were included in the analysis, sickle cell disease patients as a group still had significant inverse relationships with all lung function parameters when compared to the control group. Because smoking history can be a confounder in lung function analyses, we show the data for relationships with lung function in never-smokers amongst both the control and sickle cell disease samples in Table 2. The Table shows that the highest of the correlations between lung function in sickle cell disease vs. controls was -0.652 between FEV1\% and presence of sickle cell disease. These values did not changed markedly when smokers were included in the analysis.

\section{Lung function in sickle cell disease (SCD) patients}

Lung function abnormalities in sickle cell disease (SCD), 52 sickle cell disease patients had normal lung function. Table 3 shows that $30(19.5 \%)$ sickle cell disease patients had a FEV1/FVC ratio of less than $70 \%$ indicating obstruction. $12(7.8 \%)$ had a mixed obstructiverestrictive ventilatory defect and $60(39 \%)$ had a purely restrictive defect. $4(5.4 \%)$ of the 74 controls had a restrictive defect. Figure 1 shows the distribution of FVC\% in the sickle cell disease patients. 72 (46.8\%) sickle cell disease patients were found to have a restrictive defect (including those with mixed defects).

Lung function and ACS, there was no statistically significant difference in the measures of lung function between sickle cell disease patients with a history of acute chest syndrome and those who never had an episode. However, patients with one or less acute chest syndrome episodes had a FEV1\% of $75.16(13.25 \%)$ vs. $65.74(10.89 \%)$ in those with two or more episodes $(\mathrm{p}=0.030)$. There was also a non-significant trend toward lower FVC\%: one or less acute chest syndrome episodes had a FEV1\% of $84.0(16.35 \%)$ vs. 77.9 (15.3\%), p=0.255.

\section{Lung function and haemoglobin in SCD patients}

Bivariate analyses showed that stable haemoglobin $(\mathrm{Hb})$ was inversely correlated to age $(\mathrm{r}=-0.214, \mathrm{p}=0.009)$, BMI $(0.270,0.001)$, abnormal (restrictive or obstructive) lung function $(-0.286, \mathrm{p}<0.001)$, presence of a restrictive ventilatory defect $(-0.261, \mathrm{p}=0.001)$, CRP $(\log )$ $(-0.240,0.005)$ and FVC\% $(0.286<0.001)$ but not other indices of lung function, history of smoking or height.

When sickle cell disease patients were categorized by lung function (Table 3 ) there was a trend $(\mathrm{r}=-0.269, \mathrm{p}=0.001)$ in mean (SD) $\mathrm{Hb}$ amongst sickle cell disease patients grouped as follows: (Group A) normal lung function $\mathrm{Hb}=9.66$ (2.25); (Group B) either obstruction or restriction but not both $\mathrm{Hb}=8.36$ (2.03) and (Group C) both obstruction and restriction $\mathrm{Hb}=8.13(2.53)$. Application of one-way ANOVA confirmed the relationship and post hoc (LSD) testing showed that Groups B and C were both different from Group A but did not differ significantly from each other.

Multivariate linear regression with sickle cell patient plasma haemoglobin as outcome variable showed that regardless of age and gender there was a significant relationship between plasma haemoglobin and restrictive lung function as well as CRP $(\log )$ (Table 4). Figure 2 illustrates the relationship between plasma haemoglobin and FVC\% with correlation $\mathrm{r}=0.286, \mathrm{p}<0.001$, in sickle cell disease patients.

\section{Discussion}

This is the first study of lung function and inflammation in sickle

\begin{tabular}{|l|c|c|}
\hline Variable & B & p-value \\
\hline Restrictive ventilatory defect & -0.689 & 0.049 \\
\hline Age & -0.036 & 0.014 \\
\hline BMI & 0.179 & $<0.001$ \\
\hline CRP (log) & -0.469 & 0.001 \\
\hline Male Gender & 0.915 & 0.010 \\
\hline
\end{tabular}

\section{$\mathrm{BMI}=$ Body Mass Index}

$\mathrm{CRP}(\log )=$ Natural Logarithm of $\mathrm{C}$ reactive protein measured in $\mathrm{mg} / \mathrm{L}$

Table 4: Linear regression with haemoglobin as outcome variable in 154 sickle cell disease patients.

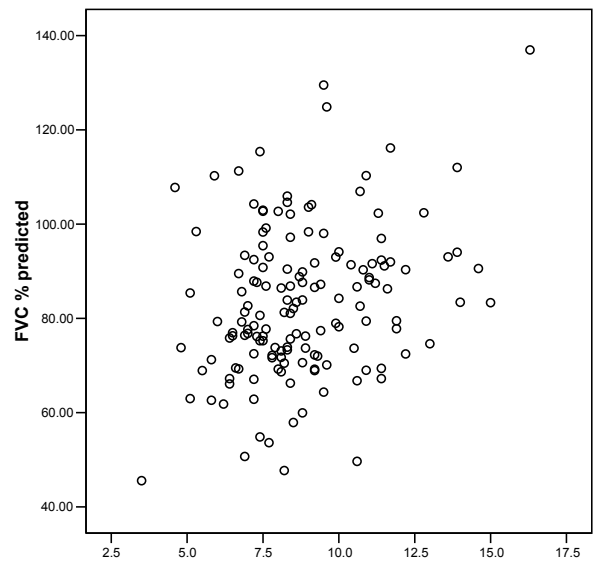

Figure 2: The relation between FVC\% predicted and $\mathrm{Hb}$ in 149 sickle cell patients, $r=0.286, p<0.001$. 
cell disease patients. In this study we found a prevalence of $18 \%$ with the acute chest syndrome (ACS) in our sickle cell disease patients. We found that about one-fifth of our sickle cell disease patients had an obstructive ventilatory defect and 39\% had a restrictive-only ventilatory defect and so taken together $66 \%$ of sickle cell disease patients studied had abnormal lung function. We found that recurrent acute chest syndrome episodes were associated with a lower FEV1\%. Plasma haemoglobin was lower in patients with a restrictive ventilatory defect and those with higher CRP.

We found a predominantly restrictive ventilatory defect in $47 \%$ of our sickle cell disease patients. This is less so, than was found in Jamaica (60\%) [17]. In a study conducted at the Montreal Children's Hospital decreased lung volumes were thought to be the result of smaller thoraxes and a disparity between torso and limb growth among children with sickle cell disease [16]. Sylvester et al. [1] also found reduced height and lung volumes in children with sickle cell disease compared to controls and reported that this restrictive tendency increases with increasing age. Therefore, there is a tendency towards restriction among sickle cell disease patients from early childhood which progresses into adulthood and with which our results are consistent. In addition, unlike the Jamaican and USA studies, not all of our patients were homozygous for SS disease, the latter of which has been linked to disease severity [18].

Although the dominant pattern of abnormal lung function was restrictive, $19.5 \%$ of our sickle cell disease patients were found to have an obstructive defect and $7.8 \%$ had mixed disease. Vendramini et al. [17] reported a high prevalence of airway hyperresponsiveness and obstructive disease in adult patients with sickle cell disease when compared to controls, though obstruction was not seen in the Jamaican study [19]. Post-bronchodilator spirometry was used in our patients. Thus, we are unable to comment on any relationships with reversibility or airway hyperresponsiveness. However an in vitro study of sickle cell disease using the mouse model has found increased large and small airway resistance in the airways, if sickle cell disease mice and mechanism may underlie the spirometric lesions seen in our patients [20].

Our study is only the second study to report a relationship between frequent acute chest syndrome episodes and lung function in sickle cell disease in West Indian patients. The Jamaican study which reported this relationship above, found that $32.5 \%$ of sickle cell disease patients had two or more acute chest syndrome episodes as compared to $7 \%$ in our study [19]. Our patients of similar height, tended to have a greater weight and this may perhaps indicate a better nutritional status than their Jamaican counterparts. Nutritional status has been shown to ameliorate severity in sickle cell disease in one in vitro study [21].

We found that there is an inverse relationship between serum CRP and plasma haemoglobin in our sickle cell disease patients. The relation between systemic inflammation and sickle cell disease has previously been shown in children [22] and adolescents [23]. In several mouse models, inflammatory markers have been found in the sickle cell disease lung [24]. Importantly interleukin-6 (IL-6), a precursor of CRP, was elevated about two-fold in the sickle cell lung. Thus apart from a systemic stimulus to CRP formation in sickle cell disease there may also be a pulmonary stimulus as has been suggested in another model of chronic lung disease $[25,26]$.

It has been shown that lower baseline haemoglobin is associated with an increased rate of painful episodes and morbidity in sickle cell disease patients [8], and that the percentage of haemoglobin $\mathrm{F}$ is a powerful predictor of clinical severity in these patients [27]. Our study showed that there is an association between lower steady-state haemoglobin and the presence of a restrictive ventilatory defect. Moreover the lower the haemoglobin level, the higher the CRP, suggesting that chronic systemic inflammation is likely to play a role in the pathophysiology of the restrictive lung disease in these patients. These relationships support the hypothesis that the steady-state haemoglobin may be considered a surrogate marker of severity in the sickle cell disease in our population.

The inability to fully sample the entire patient population registered at the Haematology Clinic was a limitation to the study. Post-bronchodilator spirometry was used and this may have masked any reversible obstructive defect in the sample population. We did not perform postbronchodilator spirometry on our controls as they were asymptomatic and had no history of medical illness. If anything this would have caused us to under estimate the difference in lung function parameters between controls and sickle cell disease patients. The Hankinson prediction equations for Afro-Americans were used in this study to define normal ranges for lung function parameters as no reference ranges for a Trinidadian population are available [15]. We overcame this limitation by using a control group. Further we relied exclusively on hospital notes thus we may have excluded those patients who may have been treated in the community, if any. Finally, smoking data was obtained primarily by self-reporting and this may have led to an under-representation of the true number of smokers in the two sample populations.

In conclusion, this study confirms that in the Trinidadian population those with sickle cell disease tend to have lower lung function parameters than healthy controls consistent with a restrictive defect. In sickle cell patients low stable plasma haemoglobin is more likely in patients who have restricted lung function, who are older and who have more systemic inflammation and low BMI. Recently molecular markers rather than biophysical markers of severity have received most attention in sickle cell disease [28]. Throughout the last century, sickle cell disease has been studied at several physiologic levels (molecular, tissue, cellular and biochemical) little consensus has emerged on markers of disease severity $[29,30]$. Though our study was not designed to detect markers of severity in sickle cell disease, the relation of the easily measured plasma haemoglobin with FVC\% and CRP lends support once again to the hypothesis that stable haemoglobin can be taken as a surrogate marker of severity in sickle cell disease.

\section{Acknowledgements}

The authors would like to acknowledge the contributions of doctors, nurses and all supporting staff of Ward 44 Port of Spain General Hospital as well as the laboratory staff at Eric Williams Medical Sciences Complex.

\section{Reference}

1. Sylvester KP, Patey RA, Milligan P, Dick M, Rafferty GF, et al. (2004) Pulmonary function abnormalities in children with sickle cell disease. Thorax 59: 67-70.

2. Wethers DL (2000) Sickle cell disease in childhood: Part I. Laboratory diagnosis, pathophysiology and health maintenance. Am Fam Physician 62: 1013-1020, 1027-1028.

3. Mehta SR, Afenyi-Annan A, Byrns PJ, Lottenberg R (2006) Opportunities to improve outcomes in sickle cell disease. Am Fam Physician 74: 303-310.

4. Taylor C, Carter F, Poulose J, Rolle S, Babu S, et al. (2004) Clinical presentation of acute chest syndrome in sickle cell disease. Postgrad Med J 80: 346-349.

5. Styles LA, Schalkwijk CG, Aarsman AJ, Vichinsky EP, Lubin BH, et al. (1996) Phospholipase A2 levels in acute chest syndrome of sickle cell disease. Blood 87: 2573-2578.

6. Charles KS, Osagie K, Battini RK (2006) Hospital admissions for acute painfu crisis in Trinidad and Tobago. Are the British Committee for Standards in Haematology (BCSH) guidelines applicable? Clin Lab Haematol 28: 299-302.

7. Castro O, Brambilla DJ, Thorington B, Reindorf CA, Scott RB, et al. (1994) The 
Citation: Williams K, Rios M, Dottin N, Hughes S, Strachan D, et al. (2012) Lung Function and Inflammation in Adult Sickle Cell Disease in a West Indian Sickle Cell Cohort. J Pulmon Resp Med 2:129. doi:10.4172/2161-105X.1000129

acute chest syndrome in sickle cell disease: incidence and risk factors. The Cooperative Study of Sickle Cell Disease. Blood 84: 643-649.

8. Hargrave DR, Wade A, Evans JP, Hewes DK, Kirkham FJ (2003) Nocturnal oxygen saturation and painful sickle cell crises in children. Blood 101: 846-848.

9. Hedo CC, Aken'ova YA, Okpala IE, Durojaiye AO, Salimonu LS (1993) Acute phase reactants and severity of homozygous sickle cell disease. J Intern Med 233: 467-470.

10. Sullivan KJ, Kissoon N, Duckworth LJ, Sandler E, Freeman B, et al. (2001) Low exhaled nitric oxide and a polymorphism in the NOS I gene is associated with acute chest syndrome. Am J Respir Crit Care Med 164: 2186-2190.

11. Hibbert JM, Hsu LL, Bhathena SJ, Irune I, Sarfo B, et al. (2005) Proinflammatory cytokines and the hypermetabolism of children with sickle cell disease. Exp Biol Med (Maywood) 230: 68-74.

12. (1996) AARC Clinical Practice Guideline Spirometry, 1996 Update. Respir Care 41: 629-636.

13. Behrendt CE (2005) Mild and moderate-to-severe COPD in nonsmokers: distinct demographic profiles. Chest 128: 1239-1244.

14. Miller MR, Crapo R, Hankinson J, Brusasco V, Burgos F, et al. (2005) General considerations for lung function testing. Eur Respir J 26: 153-161.

15. Pianosi P, D’Souza SJ, Charge TD, Esseltine DE, Coates AL (1993) Pulmonary function abnormalities in childhood sickle cell disease. J Pediatr 122: 366-371.

16. Hankinson JL, Odencrantz JR, Fedan KB (1999) Spirometric reference values from a sample of the general U.S. population. Am J Respir Crit Care Med 159: 179-187.

17. Vendramini EC, Vianna EO, De Lucena Angulo I, De Castro FB, Martinez JA, et al. (2006) Lung function and airway hyperresponsiveness in adult patients with sickle cell disease. Am J Med Sci 332: 68-72.

18. Bender MA, Hobbs W (2012) Sickle cell disease. Pagon RA, Bird TD, Dolan CR, Stephens K, Adam MP, editors. GeneReviews ${ }^{\text {TM }}$ [Internet]. (2012) Seattle (WA): University of Washington, Seattle; 1993-2003 Sep 15 [updated 2012 Feb 09].

19. Knight-Madden JM, Forrester TS, Lewis NA, Greenough A (2010) The impact of recurrent acute chest syndrome on the lung function of young adults with sickle cell disease. Lung 188: 499-504.

20. Pritchard KA Jr, Feroah TR, Nandedkar SD, Holzhauer SL, Hutchins W, et al (2012) Effects of experimental asthma on inflammation and lung mechanics in sickle cell mice. Am J Respir Cell Mol Biol 46: 389-396.

21. Archer DR, Stiles JK, Newman GW, Quarshie A, Hsu LL, et al. (2008) C-reactive protein and interleukin- 6 are decreased in transgenic sickle cell mice fed a high protein diet. J Nutr 138: 1148-1152.

22. Krishnan S, Setty Y, Betal SG, Vijender V, Rao K, et al. (2010) Increased levels of the inflammatory biomarker C-reactive protein at baseline are associated with childhood sickle cell vasocclusive crises. Br J Haematol 148: 797-804

23. Akohoue SA, Shankar S, Milne GL, Morrow J, Chen KY, et al. (2007) Energy expenditure, inflammation, and oxidative stress in steady-state adolescents with sickle cell anemia. Pediatr Res 61: 233-238.

24. Belcher JD, Bryant CJ, Nguyen J, Bowlin PR, Kielbik MC, et al. (2003) Transgenic sickle mice have vascular inflammation. Blood 101: 3953-3959.

25. Bhowmik A, Seemungal TA, Sapsford RJ, Wedzicha JA (2000) Relation of sputum inflammatory markers to symptoms and lung function changes in COPD exacerbations. Thorax 55: 114-120.

26. Wedzicha JA, Seemungal TA, MacCallum PK, Paul EA, Donaldson GC, et al. (2000) Acute exacerbations of chronic obstructive pulmonary disease are accompanied by elevations of plasma fibrinogen and serum IL-6 levels. Thromb Haemost 84: 210-215.

27. Kotila TR, Shokunbi WA (2003) Haemoglobin F levels in healthy Nigerian adults. West Afr J Med 22: 143-145.

28. Thompson AA (2011) Primary prophylaxis in sickle cell disease: is it feasible? Is it effective? Hematology Am Soc Hematol Educ Program 2011: 434-439.

29. Wood DK, Soriano A, Mahadevan L, Higgins JM, Bhatia SN (2012) A biophysical indicator of vaso-occlusive risk in sickle cell disease. Sci Trans Med 4: 123 ra26.

30. Alsultan A, Aleem A, Ghabbour H, AlGahtani FH, Al-Shehri A, et al. (2012) Sickle cell disease subphenotypes in patients from Southwestern Province of Saudi Arabia. J Pediatr Hematol Oncol 34: 79-84. 